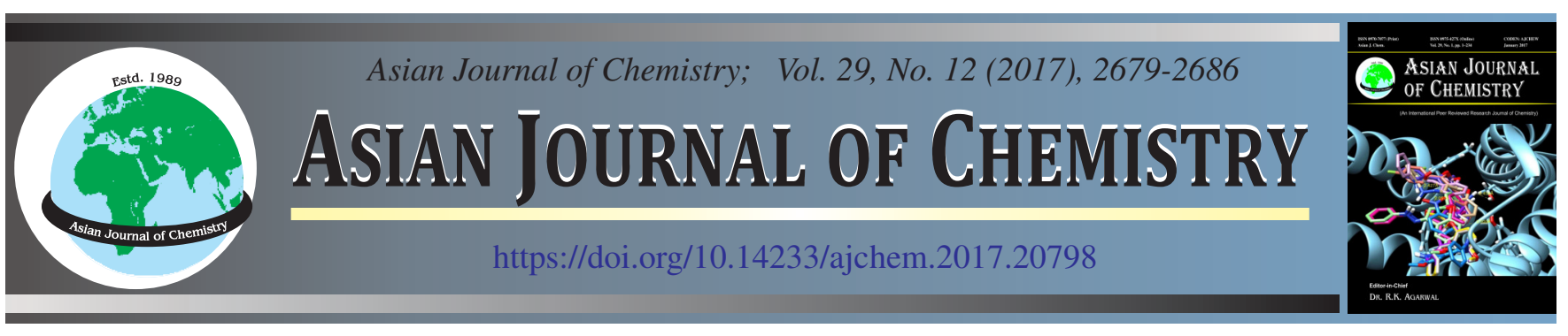

\title{
Synthesis of N-Containing Heterocycles via Mechanochemical Grinding and Conventional Techniques
}

\section{Amin F.M. Fahmy ${ }^{1}$, Amira A. El-Sayed ${ }^{1, *}$, Magdy M. Hemdan ${ }^{1}$, Aya I. Hassaballah ${ }^{1}$ and Ahmed F. Mabied ${ }^{2,3}$}

${ }^{1}$ Department of Chemistry, Faculty of Science, Ain Shams University, 11566, Abbasia, Cairo Egypt

${ }^{2}$ X-ray Crystallography Lab., Solid State Physics Department, National Research Center, Dokki, Cairo, Egypt

${ }^{3}$ Department of Basic Sciences, October High Institute for Engineering and Technology, 3rd District, 2nd Zone, 6th of October City, Egypt

*Corresponding author: E-mail: amira_aa47@hotmail.com

Mechano heterocyclic chemistry is a recent quickly growing technique draws the attention of hetrocyclic chemists towards the use of grindstone technique in a solvent free green efficient clean synthesis of many heterocyclic systems. $\alpha, \beta$-Epoxy ketones were used as a unique scaffold for synthesis of stable hydroxyazoles. The key advantage of grinding technique over the conventional thermal technique includes its simple, solvent free conditions, as well as facile work up with high yield economy. It is also successful in achieving three of the green chemistry objectives of a solvent free, high atom economy, save energy thus combining the features of both economic and environmental advantages.

Keywords: Green chemistry, Pyrazoles, Oxazoles, Imidazolidines, Oxazolidines.

\section{INTRODUCTION}

Oxazoles, pyrazoles and imidazoles derivatives are important biological agents. Oxazoles have a broad spectrum of biological and pharmacological activities such as antibacterial, antifungal, pesticidal, insecticidal, anti-inflammatory and antitumor [1]. Isoxazole derivatives exhibit various biological activities such as, antibacterial, anticonvulsant, anticholestermic, anticancer, anthelmintics. Antiinflammatory, adenosine antagonist, fungicidal, herbicidal, hypoglycemic, muscle relaxant, nematocidal, insecticidal, antiviral and antimicrobial [2]. Pyrazoles used as antitumor, antibacterial and antifungal, antiviral, antiparasitic, antitubercular, insecticidal agents, antiinflammatory, antidiabetic, aesthetic and analgesic properties [3]. Imidazole possess extensive spectrum of biological activities such as antibacterial, anticancer, antitubercular, antifungal, analgesic and anti-HIV activities [4].

Recently, mechanochemistry offers a cleaner, more efficient alternative to a majority of conventional transformations [5], however, mechano heterocyclic chemistry (MHC) [5,6] draws the attention of heterocyclic chemists towards the uses of grindstone technique in green efficient synthesis of many heterocyclic systems [7-12].

In continuation of our work on uses of green mechanochemical synthesis of heterocyclic systems [13,14], we present herein a comparative study between the efficient green mechano (grindstone) and conventional (thermal) techniques for the synthesis of the target heterocyclic compounds from the reaction of $\alpha, \beta$-keto-oxarines with different nucleophiles. Different characterization methods were used; FTIR, ${ }^{1} \mathrm{H}$ NMR, ${ }^{13} \mathrm{C}$ NMR, MS, in addition Single crystal X-ray study for identifying the stereo chemical structure of 1,3,5-triphenyl-4,5dihydro-1H-pyrazol-4-ol (2c).

\section{EXPERIMENTAL}

All the reagents and solvents were purchased from Merck (Germany) and were used as received; commercially available solvents were used without further purifications for crystallizations of the obtained products (Adwek-Egypt). Melting points were measured on an electro-thermal melting point apparatus and were uncorrected. The elemental analyses were done on a Vario El Elementar. The IR spectra were recorded on FTIR Maltson (infinity series) spectrophotometer as $\mathrm{KBr}$ discs. The ${ }^{1} \mathrm{H}$ NMR and ${ }^{13} \mathrm{C}$ NMR spectra were measured on Varian Gemini $300 \mathrm{MHz}$ spectrometer, with chemical shift ( $\delta$ ) expressed in ppm downfield from TMS as internal standard, in $\mathrm{CDCl}_{3}$ or DMSO- $d_{6}$. Mass spectra were determined on Shimadzu GC-MSQP 1000 EX instrument operating at $70 \mathrm{eV}$. TLC was run using TLC aluminum sheets silica gel $F_{254}$ (Merck). It was carried out the monitoring of the progress of all reactions and homogeneity of the synthesized compounds. X-ray study 
was performed at X-ray Crystallography Laboratory, Physics Division, National Research Center (NRC), Egypt. Single crystal diffractometer equipped with a CCD detector and a liquid-nitrogen low-temperature device, on a Bruker-Nonius FR590 X-ray generator with a molybdenum sealed tube. The Kappa CCD, includes the state-of-the-art technologies for rapid, precise and accurate data collection even with small crystals. A charge-coupled device (CCD) detector allows many diffraction spots to be collected.

General procedure for synthesis of compounds 1a,b: Hydrogen peroxide $(8 \mathrm{~mL}, 30 \%)$ was added portion wise to aryl-1-phenylprop-2-en-1-ones $(0.01 \mathrm{~mol})$ in acetone $(30 \mathrm{~mL})$, methanol $(10 \mathrm{~mL})$ containing $\mathrm{KOH}(1 \mathrm{~g})$ at $0{ }^{\circ} \mathrm{C}$ in an ice bath with stirring for (75-120 min). The solid product was obtained, filtered off and recrystallized from light petroleum ether (60/ $\left.80{ }^{\circ} \mathrm{C}\right)[15,16]$.

Reaction of $\alpha, \beta$-epoxy ketones $1 \mathrm{a}$ and $1 \mathrm{~b}$ with hydrazine hydrate and phenylhydrazine:

Under green solvent free grinding: A mixture of equivalent amounts of $\alpha, \beta$-epoxy ketones $\mathbf{1 a} /$ or $\mathbf{1 b}(3 \mathrm{mmol})$ with hydrazine hydrate/or phenyl hydrazine $(6 \mathrm{mmol})$ was mixed for 5-7 min in a porcelain mortar and pestle in the presence of a few drops of acetic anhydride (Table-1). Upon completion of the reaction as monitored by TLC, the reaction mixture turned coloured solid mass, washed with cold water and recrystallized from suitable solvents to give compounds $\mathbf{2 a - 2 d}$.

Under conventional thermal method: A solution of $\alpha, \beta$ epoxy ketones 1a or $\mathbf{1 b}(3 \mathrm{mmol})$ in ethanol $(30 \mathrm{~mL})$ was refluxed for 6-14 $\mathrm{h}$ with hydrazine hydrate and/or phenyl hydrazine $(6 \mathrm{mmol})$ (monitored by TLC), then the reaction mixture was vacuum-distilled to about half volume. The solid product was obtained after cooling, filtered off and recrystallized from the proper solvent to give same compounds $2 \mathbf{a}$ and $\mathbf{2 b}$.

3,5-Diphenyl-4,5-dihydro-1H-pyrazol-4-ol (2a): Yellow crystals $($ EtOH $)$, m.p. $=200-202{ }^{\circ} \mathrm{C},{ }^{1} \mathrm{H}$ NMR $\left(\right.$ DMSO- $\left.d_{6}\right) \delta$ : 4.54 (d, 1H, $J=6.6 \mathrm{~Hz}), 4.98$ (d, 1H, $J=6.3 \mathrm{~Hz}$ ), 5.93 (br. s, 1H, OH, exchangeable), 7.24-7.39 (m, 8H, Ar-H), 7.60 (br. s, $1 \mathrm{H}, \mathrm{NH}$, exchangeable), $7.73(\mathrm{~d}, 2 \mathrm{H}, J=7.8 \mathrm{~Hz})$. IR ( $\mathrm{KBr}$, $\left.v_{\max }, \mathrm{cm}^{-1}\right): 3490(\mathrm{OH}), 3288,3135(\mathrm{NH}), 3086\left(\mathrm{C}-\mathrm{H}_{\text {arom }}\right)$, 2920, $2841\left(\mathrm{C}-\mathrm{H}_{\text {alkyl }}\right), 1584(\mathrm{C}=\mathrm{N}), 694,754 \delta_{5 \mathrm{H}} . \mathrm{MS}(70 \mathrm{eV})$ $\mathrm{m} / \mathrm{z}(\%): 221\left(\mathrm{M}^{+\cdot}-\mathrm{OH}, 14\right), 220\left(\mathrm{M}^{+\cdot}-\mathrm{H}_{2} \mathrm{O}, 66\right), 219\left(\mathrm{M}^{+\cdot}-\right.$ $\left.\left(\mathrm{H}_{2} \mathrm{O}+\mathrm{H}\right), 5\right), 191$ (13), 165 (6), 134 (99), 106 (100), 105 (12), 78 (17), 77 (90). Anal. calcd. (found) for $\mathrm{C}_{15} \mathrm{H}_{14} \mathrm{~N}_{2} \mathrm{O}: \mathrm{C}, 75.61$ (75.34); H, 5.92 (5.85); N, 11.76 (11.59).

3-(Naphthalen-2-yl-5-phenyl-4,5-dihydro- $\boldsymbol{H}$-pyrazol4-ol (2b): Pale yellow crystals (benzene), m.p. $=200-201{ }^{\circ} \mathrm{C}$, ${ }^{1} \mathrm{H} \mathrm{NMR}\left(\mathrm{CDCl}_{3}\right) \delta$ : 4.41 (m, 2H), 5.52 (br. s, 1H, OH, exchangeable), 7.20-7.39 (m, 4H, Ar-H), 7.55-7.57 (m, 2H, Ar-H), 7.85-7.93 (m, 2H, Ar-H), 8.14 (d, 4H, J = 8.4 Hz), 8.50 (br. s, $1 \mathrm{H}, \mathrm{NH}$, exchangeable). ${ }^{13} \mathrm{C} \mathrm{NMR}\left(\mathrm{CDCl}_{3}\right) \delta: 45.88(1 \mathrm{C}-\mathrm{NH})$, $81.51(1 \mathrm{C}-\mathrm{OH})$, ar-C [123.85 (3CH), $128.70(4 \mathrm{CH}), 135.33$ (5CH), 135.88 (1C), 135.99 (1C), 136.17 (1C), 136.25 (1C)], $145.32(\mathrm{C}=\mathrm{N})$. IR $\left(\mathrm{KBr}, v_{\max }, \mathrm{cm}^{-1}\right): 3420(\mathrm{OH}), 3266,3135$ $(\mathrm{NH}), 3085,3062\left(\mathrm{C}-\mathrm{H}_{\text {arom }}\right), 2923,2842\left(\mathrm{C}-\mathrm{H}_{\text {alkyl }}\right), 1598$ $(\mathrm{C}=\mathrm{N}), 698,754 \delta_{5 \mathrm{H}} . \mathrm{MS}(70 \mathrm{eV}) \mathrm{m} / \mathrm{z}(\%): 289\left(\mathrm{M}^{+}+1,24\right)$, $288\left(\mathrm{M}^{+}, 100\right), 271\left(\mathrm{M}^{+\cdot}-\mathrm{OH}, 10\right), 270\left(\mathrm{M}^{+\cdot}-\mathrm{H}_{2} \mathrm{O}, 42\right), 241(8)$, 165 (6), 184 (47), 154 (90), 127 (50), 106 (40), 77 (19). Anal. calcd. (found) for $\mathrm{C}_{19} \mathrm{H}_{16} \mathrm{~N}_{2} \mathrm{O}: \mathrm{C}, 79.14$ (78.93); H, 5.59 (5.23); N, 9.72 (9.66).

1,3,5-Triphenyl-4,5-dihydro-1H-pyrazol-4-ol (2c): Yellow crystals $\left(\right.$ EtOH), m.p. $=140-141{ }^{\circ} \mathrm{C},{ }^{1} \mathrm{H}$ NMR (DMSO$\left.d_{6}\right) \delta: 4.98(\mathrm{~d}, 1 \mathrm{H}, J=2.7 \mathrm{~Hz}), 5.13(\mathrm{~d}, 1 \mathrm{H}, J=2.7 \mathrm{~Hz}), 6.41$ (br. s, 1H, OH, exchangeable), $6.71(\mathrm{t}, 1 \mathrm{H}, J=7.2 \mathrm{~Hz}), 7.05$ (d, 2H, $J=7.5 \mathrm{~Hz}), 7.15-7.43(\mathrm{~m}, 10 \mathrm{H}, \mathrm{Ar}-\mathrm{H}), 7.84$ (d, 2H, $J$ $=7.2 \mathrm{~Hz})$. IR $\left(\mathrm{KBr}, v_{\max }, \mathrm{cm}^{-1}\right): 3261(\mathrm{OH}), 3060,3027(\mathrm{C}-$ $\left.\mathrm{H}_{\text {arom }}\right), 2929\left(\mathrm{C}-\mathrm{H}_{\text {alkyl }}\right), 1597(\mathrm{C}=\mathrm{N}), 691,750 \delta_{5 \mathrm{H}} . \mathrm{MS}(70 \mathrm{eV})$ m/z (\%): $297\left(\mathrm{M}^{+\cdot}-\mathrm{OH}, 14\right), 296\left(\mathrm{M}^{++}-\mathrm{H}_{2} \mathrm{O}, 62\right), 295\left(\mathrm{M}^{+}-\right.$ $\left.\left(\mathrm{H}_{2} \mathrm{O}+\mathrm{H}\right), 38\right), 181$ (23), 180 (20), 133 (7), 91 (53), 77 (100). Anal. calcd. (found) for $\mathrm{C}_{21} \mathrm{H}_{18} \mathrm{~N}_{2} \mathrm{O}$ : C, 80.23 (79.96); $\mathrm{H}, 5.77$ (5.63); N, 8.91 (9.12).

3-(Naphthalen-2-yl)-1,5-diphenyl-4,5-dihydro-1Hpyrazol-4-ol (2d): Orange crystals (light petroleum $60 / 80{ }^{\circ} \mathrm{C}$ ),

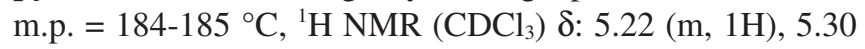
(m, 1H), 8.09 (br. s, 1H, OH, exchangeable), 6.71 (t, 2H, $J=$ $7.5 \mathrm{~Hz}$ ), 7.15-7.48 (m, 10H, Ar-H), 7.80-7.87 (m, 4H, Ar-H), $8.18(\mathrm{~d}, 1 \mathrm{H}, J=9.0 \mathrm{~Hz}) .{ }^{13} \mathrm{C} \mathrm{NMR}\left(\mathrm{CDCl}_{3}\right) \delta: 45.96(1 \mathrm{C}-\mathrm{NH})$, 83.67 (1C-OH), ar-C [113.34 (2CH), 120.09 (1CH), 123.77 $(3 \mathrm{CH}), 125.19(2 \mathrm{CH}), 125.79(2 \mathrm{CH}), 126.29(2 \mathrm{CH}), 128.65$ (2CH), $129.29(3 \mathrm{CH}), 133.46(1 \mathrm{C}), 135.79(1 \mathrm{C}), 136.09$ (1C), $136.40(1 \mathrm{C}), 138.10(1 \mathrm{C})], 147.04(\mathrm{C}=\mathrm{N}) . \mathrm{IR}\left(\mathrm{KBr}, \mathrm{v}_{\max }, \mathrm{cm}^{-1}\right)$ : $3539(\mathrm{OH}), 3045\left(\mathrm{C}-\mathrm{H}_{\text {arom }}\right), 2920\left(\mathrm{C}-\mathrm{H}_{\text {alkyl }}\right), 1596(\mathrm{C}=\mathrm{N}), 695$, $748 \delta_{5 \mathrm{H}} . \mathrm{MS}(70 \mathrm{eV}) \mathrm{m} / \mathrm{z}(\%): 364\left(\mathrm{M}^{+}, 90\right), 365\left(\mathrm{M}^{+}+1,33\right)$, 347( $\left.\mathrm{M}^{+}-\mathrm{OH}, 9\right), 346\left(\mathrm{M}^{+\cdot}-\mathrm{H}_{2} \mathrm{O}, 13\right), 181$ (100), 180 (20), 155 (17), 104 (11), 91 (45), 77 (27). Anal. calcd. (found) for $\mathrm{C}_{25} \mathrm{H}_{20} \mathrm{~N}_{2} \mathrm{O}$ : C, 82.39 (82.41); H, 5.53 (5.33); N, 7.69 (7.55).

Reaction of $\alpha, \beta$-epoxy ketones 1a and $1 b$ with hydroxylamine hydrochloride:

Under conventional thermal method: A solution of 1a or $\mathbf{1 b}(3 \mathrm{mmol})$ in benzene $(30 \mathrm{~mL})$ and few drops of triethylamine was refluxed for 12-24 $\mathrm{h}$ with an equivalent amount of hydroxylamine hydrochloride (6 mmol), (TLC monitoring). A solid product was obtained after cooling, was filtered off and recrystallized from suitable solvents to give $\mathbf{3 a}$ or $\mathbf{3 b}$. The reaction failed under grinding conditions,

3,5-Diphenyl-4,5-dihydroisoxazol-4-ol (3a) (conven.): Pale yellow crystals $($ EtOH $)$, m.p. $=158-160{ }^{\circ} \mathrm{C},{ }^{1} \mathrm{H}$ NMR $\left(\mathrm{DMSO}_{6}\right) \delta: 5.32-5.41(\mathrm{~m}, 2 \mathrm{H}), 6.49$ (br. s, $1 \mathrm{H}, \mathrm{OH}$, exchangeable), 7.33-7.45 (m, 8H, Ar-H), 7.78 (d, 2H, $J=7.8$ $\mathrm{Hz})$. IR (KBr, $\left.v_{\max }, \mathrm{cm}^{-1}\right): 3313(\mathrm{OH}), 3065,3026\left(\mathrm{C}-\mathrm{H}_{\text {arom }}\right)$, 2922, $2851\left(\mathrm{C}-\mathrm{H}_{\text {alkyl }}\right), 1595(\mathrm{C}=\mathrm{N}), 687,758 \delta_{5 \mathrm{H}} . \mathrm{MS}(70 \mathrm{eV})$ $m / z$ (\%): 239 ( $\left.\mathbf{M}^{+}, 9\right), 222\left(\mathbf{M}^{+-}-\mathrm{OH}, 3\right), 221\left(\mathbf{M}^{+-}-\mathrm{H}_{2} \mathrm{O}, 4\right), 193$ (17), 165 (7), 133 (52), 120 (60), 104 (83), 85 (89), 77 (74), 71 (100). Anal. calcd. (found) for $\mathrm{C}_{15} \mathrm{H}_{13} \mathrm{NO}_{2}$ : C, 75.30 (75.18); H, 5.48 (5.22); N, 5.85 (5.50).

3-(Naphthalen-2-yl)-5-phenyl-4,5-dihydroisoxazol-4-ol (3b) (conven.): Pale yellow crystals (light petroleum ether 60/ $\left.80{ }^{\circ} \mathrm{C}\right)$, m.p. $=168-170{ }^{\circ} \mathrm{C},{ }^{1} \mathrm{H}$ NMR $\left(\mathrm{DMSO}-d_{6}\right) \delta: 5.47-5.54$ (m, 2H), 6.62 (br. s, 1H, OH, exchangeable), 7.37-7.57 (m, 7H, Ar-H), 7.92-7.96 (m, 4H, Ar-H), 8.30 (m, 1H, Ar-H). ${ }^{13} \mathrm{C}$ NMR (DMSO- $\left.d_{6}\right) \delta$ : $82.86(1 \mathrm{C}-\mathrm{OH}), 89.42$ (1C-O), ar-C [123.72 (2CH), $125.75(3 \mathrm{CH}), 127.29(2 \mathrm{CH}), 127.70$ $(2 \mathrm{CH}+1 \mathrm{C}), 128.40(3 \mathrm{CH}), 132.60$ (1C), 133.39 (1C), 138.67 (1C)], $157.65(\mathrm{C}=\mathrm{N})$. IR (KBr, $\left.v_{\max }, \mathrm{cm}^{-1}\right): 3370(\mathrm{OH}), 3048$ $\left(\mathrm{C}-\mathrm{H}_{\text {arom }}\right), 2923,2852\left(\mathrm{C}-\mathrm{H}_{\text {alkyl }}\right), 1613(\mathrm{C}=\mathrm{N}), 691,749 \delta_{5 \mathrm{H}}$. MS (70 eV) m/z (\%): $289\left(\mathrm{M}^{+}, 0.3\right), 274$ (6), 269 (13), 228 
(12), 194 (7), 155 (30), 127 (32), 108 (100), 91 (15). Anal. calcd. (found) for $\mathrm{C}_{19} \mathrm{H}_{15} \mathrm{NO}_{2}$ : C, 78.87 (78.69); H, 5.23 (5.18); $\mathrm{N}, 4.84$ (5.02).

\section{Reaction of $\alpha, \beta$-epoxy ketones $1 \mathrm{a}$ and $1 \mathrm{~b}$ with urea,} thiourea, guanidine hydrochloride and semicarbazide

Under green solvent free grinding; A mixture of equivalent amounts of $\alpha, \beta$-epoxy ketones $\mathbf{1 a}$ or $\mathbf{1 b}(3 \mathrm{mmol})$ with urea (3 mmol) was mixed for 2-3 min in a porcelain mortar and pestle in the presence of a few drops of acetic anhydride (Table1). Upon completion of the reaction as monitored by TLC, the reaction mixture turned coloured solid mass, washed with cold water and recrystallized from suitable solvents to give compounds 4a,b. Similar treatment was carried out in case thiourea with time 4-10 min to give $\mathbf{4 c , d}$ and semicarbazide within 8 min to give 6 and 7, while the reaction was failed with guanidine.

Under conventional thermal method: A solution of compounds 1a or $1 \mathbf{b}$ ( $3 \mathrm{mmol})$ in ethanol $(30 \mathrm{~mL})$ was refluxed for $2-3 \mathrm{~h}$ with urea $(3 \mathrm{mmol})$ in the presence of a catalytic amount of potassium hydroxide (monitored by TLC), then the reaction mixture was vacuum-distilled to about half volume and acidified with dilute hydrochloric acid. A solid product was obtained, filtered off and recrystallized from a proper solvent to give the same compound $\mathbf{4 a}, \mathbf{b}$. Similar treatment was carried out in case thiourea to give compounds $\mathbf{4 c}, \mathbf{d}$, guanidine hydrochloride to give 5a,b and semicarbazide to give $\mathbf{6}$ and $\mathbf{7}$.

4-Benzoyl-5-phenylimidazolidin-2-one (4a): Pale yellow crystals $(\mathrm{EtOH})$, m.p. $=180-181{ }^{\circ} \mathrm{C},{ }^{1} \mathrm{H}$ NMR $\left(\mathrm{DMSO}-d_{6}\right) \delta$ : $2.96(\mathrm{~d}, 1 \mathrm{H}, J=13.5 \mathrm{~Hz}), 3.47$ (d, $1 \mathrm{H}, J=13.5 \mathrm{~Hz}), 7.20-7.28$ (m, 5H, Ar-H), 7.34-7.45 (m, 3H, Ar-H), 7.62 (d, 2H, J = 7.5 Hz), 8.67 (br. s, 1H, NH, exchangeable), 10.45 (br. s, 1H, NH, exchangeable). IR (KBr, $\left.v_{\max }, \mathrm{cm}^{-1}\right): 3259,3310(\mathrm{NH}), 3060$, $3031\left(\mathrm{C}-\mathrm{H}_{\text {arom }}\right), 2976,2925\left(\mathrm{C}-\mathrm{H}_{\text {alkyl }}\right), 1715(\mathrm{C}=\mathrm{O})$, 698, 760 $\delta_{5 \mathrm{H}}$. MS (EI): $(70 \mathrm{eV}) \mathrm{m} / z(\%): 266\left(\mathrm{M}^{+\cdot}, 1.4\right), 175(80), 104$ (100), 91 (54), 77 (35), 65 (14). Anal. calcd. (found) for $\mathrm{C}_{16} \mathrm{H}_{14} \mathrm{~N}_{2} \mathrm{O}_{2}$ : C, 72.16 (72.33); H, 5.30 (5.41) ; N, 10.52 (11.67).

4-(2-Naphthoyl)-5-phenylimidazolidin-2-one (4b): Yellow crystals $(\mathrm{EtOH}), \mathrm{m} . \mathrm{p} .=229-230{ }^{\circ} \mathrm{C},{ }^{1} \mathrm{H}$ NMR $\left(\mathrm{DMSO}-d_{6}\right) \delta$ : $3.10(\mathrm{~d}, 1 \mathrm{H}, J=13.2 \mathrm{~Hz}), 3.62(\mathrm{~d}, 1 \mathrm{H}, J=13.2 \mathrm{~Hz}), 7.25-7.33$ (m, 5H, Ar-H), 7.53-7.56 (m, 2H, Ar-H), 7.80 (d, 1H, J = 8.4 $\mathrm{Hz}$ ) 7.92-8.00 (m, 3H, Ar-H), 8.14 (m, 1H, Ar-H), 8.74 (br. s, $1 \mathrm{H}, \mathrm{NH}$, exchangeable), 10.49 (br. s, $1 \mathrm{H}, \mathrm{NH}$, exchangeable). ${ }^{13} \mathrm{C}$ NMR (DMSO- $\left.d_{6}\right) \delta: 65.49$ (1C-NH), 70.36 (1C-NH), ar$\mathrm{C}[124.30(1 \mathrm{CH}), 126.57(2 \mathrm{CH}), 127.43(3 \mathrm{CH}), 128.08(4 \mathrm{CH})$, 130.49 (2CH), 132.30 (1C), 132.49 (1C), 134.82 (1C), 136.89 (1C)], $155.94(\mathrm{C}=\mathrm{O}), 175.31(\mathrm{C}=\mathrm{O}) . \mathrm{IR}\left(\mathrm{KBr}, \mathrm{v}_{\max }, \mathrm{cm}^{-1}\right)$ : 3285(NH), 3059, $3032\left(\mathrm{C}-\mathrm{H}_{\text {arom }}\right), 2922\left(\mathrm{C}-\mathrm{H}_{\text {alkyl }}\right), 1721(\mathrm{C}=\mathrm{O})$, 700, $747 \delta_{5 \mathrm{H}} . \mathrm{MS}(\mathrm{EI}):(70 \mathrm{eV}) \mathrm{m} / \mathrm{z}(\%): 316\left(\mathrm{M}^{+\cdot}, 1\right), 225$ (100), 154 (60), 91 (54), 127 (41), 91 (18), 77 (7), 65 (6). Anal. calcd. (found) for $\mathrm{C}_{20} \mathrm{H}_{16} \mathrm{~N}_{2} \mathrm{O}_{2}$ : C, 75.93 (75.71); $\mathrm{H}, 5.10$ (4.85); N, 8.86 (9.05).

4-Benzoyl-5-phenylimidazolidin-2-thione (4c): Yellow crystals $($ EtOH $)$, m.p. $=215-218{ }^{\circ} \mathrm{C},{ }^{1} \mathrm{H}$ NMR $\left(\mathrm{DMSO}-d_{6}\right) \delta$ : $3.08(\mathrm{~d}, 1 \mathrm{H}, J=13.2 \mathrm{~Hz}), 3.49$ (d, $1 \mathrm{H}, J=13.8 \mathrm{~Hz}), 7.20-7.32$ (m, 5H, Ar-H), 7.35-7.51 (m, 3H, Ar-H), 7.58-7.59 (m, 2H, Ar-H), 10.75 (br. s, 1H, NH, exchangeable), 11.49 (br. s, 1H, $\mathrm{NH}$, exchangeable). IR (KBr, $\left.v_{\max }, \mathrm{cm}^{-1}\right): 3325,3234(\mathrm{NH})$, 3087, $3063\left(\mathrm{C}-\mathrm{H}_{\text {arom }}\right), 2957,2921\left(\mathrm{C}-\mathrm{H}_{\text {alkyl }}\right), 1727(\mathrm{C}=\mathrm{O}), 1387$
$(\mathrm{C}=\mathrm{S}), 693,747 \delta_{5 \mathrm{H}} . \mathrm{MS}(\mathrm{EI}):(70 \mathrm{eV}) \mathrm{m} / z(\%): 282\left(\mathrm{M}^{+\cdot}, 2\right)$, 249 (5), 191 (4), 177 (5), 105 (93), 91 (52), 85 (85), 77 (79), 71 (100). Anal. calcd. (found) for $\mathrm{C}_{16} \mathrm{H}_{14} \mathrm{~N}_{2} \mathrm{OS}$ : C, 68.06 (67.77); H, 5.00 (5.21); N, 9.92 (9.84).

4-(2-Naphthoyl)-5-phenylimidazolidin-2-thione (4d): Pale yellow crystals (EtOH), m.p. $=186-188{ }^{\circ} \mathrm{C},{ }^{1} \mathrm{H}$ NMR $\left(\mathrm{CDCl}_{3}\right) \delta: 3.52(\mathrm{~d}, 1 \mathrm{H}, J=13.8 \mathrm{~Hz}), 3.60(\mathrm{~d}, 1 \mathrm{H}, J=14.1$ $\mathrm{Hz}$ ), 7.06-7.20 (m, 2H, Ar-H), 7.23-7.25 (m, 2H, Ar-H), 7.537.55 (m, 3H, Ar-H), 7.70 (d, 1H, $J=8.1 \mathrm{~Hz}), 7.82-7.87$ (m, $3 \mathrm{H}, \mathrm{Ar}-\mathrm{H}), 7.93$ (d, 1H, J=8.7 Hz), 8.03 (br. s, 1H, NH, exchangeable), 8.68 (br. s, 1H, NH, exchangeable). IR (KBr, $\mathrm{v}_{\max }$, $\left.\mathrm{cm}^{-1}\right)$ : 3340, $3187(\mathrm{NH}), 3060,3029\left(\mathrm{C}-\mathrm{H}_{\text {arom }}\right), 2920,2952$ $\left(\mathrm{C}-\mathrm{H}_{\text {alkyl }}\right), 1725(\mathrm{C}=\mathrm{O}), 1384(\mathrm{C}=\mathrm{S}), 698,746 \delta_{5 \mathrm{H}} . \mathrm{MS}(\mathrm{EI})$ : (70 eV) $m / z(\%): 332\left(\mathbf{M}^{+*}, 4\right), 333\left(\mathbf{M}^{+\cdot}+1,1\right), 334\left(\mathbf{M}^{++}+2\right.$, 0.33), 241 (13), 225 (3), 154 (100), 127 (42), 91 (48), 127 (41), 91 (18), 77 (11). Anal. calcd. (found) for $\mathrm{C}_{20} \mathrm{H}_{16} \mathrm{~N}_{2} \mathrm{OS}$ : C, 72.26 (72.11); H, 4.85 (4.62); N, 8.43 (8.17).

5-Benzoyl-4-phenyloxazolidin-2-one (5a) (conven.): Colourless crystals (light petroleum ether $60 / 80{ }^{\circ} \mathrm{C}$ ), m.p. $=$ 288-290 ${ }^{\circ} \mathrm{C},{ }^{1} \mathrm{H}$ NMR (DMSO- $\left.d_{6}\right) \delta: 3.06(\mathrm{~d}, 1 \mathrm{H}, J=13.5$ $\mathrm{Hz}), 3.28$ (d, 1H, $J=13.5 \mathrm{~Hz}$ ), 7.16-7.20 (m, 4H, Ar-H), 7.26 (d, 2H, $J=6.9 \mathrm{~Hz}), 7.34$ (t, 2H, $J=7.2 \mathrm{~Hz}, J=7.5 \mathrm{~Hz}$ ), 7.53 (d, $2 \mathrm{H}, J=7.2 \mathrm{~Hz}$ ), 8.37 (br. s, $1 \mathrm{H}, \mathrm{NH}$, exchangeable). IR $\left(\mathrm{KBr}, \mathrm{v}_{\max }, \mathrm{cm}^{-1}\right)$ : 3373-3285 (NH), 3055, $3027\left(\mathrm{C}-\mathrm{H}_{\text {arom }}\right)$, 2970, $\left(\mathrm{C}-\mathrm{H}_{\text {alkyl }}\right), 1702(\mathrm{C}=\mathrm{O}), 1658(\mathrm{C}=\mathrm{O}), 699,755 \delta_{5 \mathrm{H}} . \mathrm{MS}$ (EI): (70 eV) m/z (\%): $267\left(\mathrm{M}^{+\cdot}, 4\right), 253$ (56), 250 (3), 239 (65), 211 (37), 105 (72), 91 (100), 77 (72), 65 (28). Anal. calcd. (found) for $\mathrm{C}_{16} \mathrm{H}_{13} \mathrm{NO}_{3}: \mathrm{C}, 71.90$ (71.79); $\mathrm{H}, 4.90$ (4.71); N, 5.24 (5.50).

5-(2-Naphthoyl)-4-phenyloxazolidin-2-one (5b) (conven.): Colourless crystals (acetic acid), m.p. $=138-140{ }^{\circ} \mathrm{C},{ }^{1} \mathrm{H}$ NMR (DMSO- $\left.d_{6}\right) \delta: 3.21(\mathrm{~d}, 1 \mathrm{H}, J=13.2 \mathrm{~Hz}), 3.41(\mathrm{~d}, 1 \mathrm{H}, J=13.2$ Hz), 7.19-7.33 (m, 5H, Ar-H), 7.47-7.53 (m, 2H, Ar-H), 7.73 $(\mathrm{d}, 1 \mathrm{H}, J=8.4 \mathrm{~Hz}), 7.88-7.92(\mathrm{~m}, 3 \mathrm{H}, \mathrm{Ar}-\mathrm{H}), 8.0$ (m, 1H, Ar$\mathrm{H}), 8.38$ (br. s, $1 \mathrm{H}, \mathrm{NH}$, exchangeable). ${ }^{13} \mathrm{C}$ NMR (DMSO- $d_{6}$ ) $\delta: 43.13(1 \mathrm{C}-\mathrm{NH}), 71.45$ (1C-O), ar-C [123.82 (1CH), 126.24 $(2 \mathrm{CH}), 127.39(3 \mathrm{CH}), 130.31(6 \mathrm{CH}), 131.97$ (1C), 132.54 (1C), 136.09 (1C), $138.69(1 \mathrm{C})], 170.45(\mathrm{C}=\mathrm{O}), 187.54(\mathrm{C}=\mathrm{O})$. IR $\left(\mathrm{KBr}, v_{\max }, \mathrm{cm}^{-1}\right)$ : 3320, $3235(\mathrm{NH}), 3060,3030\left(\mathrm{C}-\mathrm{H}_{\text {arom }}\right)$, 2922, $2851\left(\mathrm{C}-\mathrm{H}_{\text {alkyl }}\right), 1715(\mathrm{C}=\mathrm{O}), 1645(\mathrm{C}=\mathrm{O}), 700,749 \delta_{5 \mathrm{H}}$. MS(EI) $(70 \mathrm{eV}) \mathrm{m} / \mathrm{z}(\%): 317\left(\mathrm{M}^{+\cdot}, 0.2\right), 281$ (1), 267 (1), 149 (13), 127 (14), 111 (18), 91 (13), 77 (11), 60 (100). Anal. calcd. (found) for $\mathrm{C}_{20} \mathrm{H}_{15} \mathrm{NO}_{3}$ : C, 75.70 (75.62); $\mathrm{H}, 4.76$ (4.59); $\mathrm{N}, 4.41$ (4.37).

6-Benzoyl-5-phenyl-1,3,4-oxadiazinan-2-one (6): Pale yellow crystals (light petroleum ether $60 / 80^{\circ} \mathrm{C}$ ), m.p. $=202-$ $204{ }^{\circ} \mathrm{C},{ }^{1} \mathrm{H}$ NMR (DMSO- $\left.d_{6}\right) \delta: 3.83(\mathrm{~d}, 1 \mathrm{H}, J=12.6 \mathrm{~Hz}$ ), 3.96 (d, 1H, $J=13.2 \mathrm{~Hz}$ ), 7.13-7.67 (m, 9H, Ar-H), 7.88 (m, 1H, Ar-H), 10.53 (br. s, 1H, NH, exchangeable), 13.53 (br. s, $1 \mathrm{H}, \mathrm{NH}$, exchangeable). IR (KBr, $\left.\mathrm{v}_{\max }, \mathrm{cm}^{-1}\right): 3388,3231(\mathrm{NH})$, 3061, $3028\left(\mathrm{C}-\mathrm{H}_{\text {arom }}\right), 2969,2924\left(\mathrm{C}-\mathrm{H}_{\text {alkyl }}\right), 1689,1631$ $(\mathrm{C}=\mathrm{O}), 693,756 \delta_{5 \mathrm{H}}$. MS (EI)(70 eV) $\mathrm{m} / \mathrm{z}(\%): 282\left(\mathrm{M}^{+}, 0.04\right)$, 250 (1), 237 (2), 178 (8), 150 (25), 105 (20), 104 (100), 91 (93), 77 (62), 65 (16). Anal. calcd. (found) for $\mathrm{C}_{16} \mathrm{H}_{14} \mathrm{~N}_{2} \mathrm{O}_{3}$ : C, 68.07 (67.79); H, 5.00 (4.83); N, 9.92 (9.70).

3-(Naphthalen-2-yl)-5-phenyl-1H-pyrazole-1-carboxamide (7): Yellow crystals (light petroleum ether $60 / 80{ }^{\circ} \mathrm{C}$ ), m.p. $=119-120{ }^{\circ} \mathrm{C},{ }^{1} \mathrm{H}$ NMR $\left(\mathrm{DMSO}-d_{6}\right) \delta:$ 7.09-7.19 (m, 2H, 
Ar-H), 7.59-7.67 (m, 4H, Ar-H), 7.94-7.99 (m, 5H, Ar-H), 8.09 (d, $1 \mathrm{H}, J=7.8 \mathrm{~Hz}), 8.60$ (s, 1H), 12.97 (br. s, 2H, $\mathrm{CONH}_{2}$, exchangeable). ${ }^{13} \mathrm{C}$ NMR (DMSO- $\left.d_{6}\right) \delta$ : ar-C $[125.10(5 \mathrm{CH})$, $127.55(2 \mathrm{CH}), 127.62(2 \mathrm{CH}), 128.01(2 \mathrm{CH}), 128.14(2 \mathrm{CH})$, $129.22(4 \mathrm{C})], 132.08(\mathrm{C}=\mathrm{C}), 134.87(\mathrm{C}=\mathrm{N}), 167.37(\mathrm{C}=\mathrm{O})$. IR (KBr, $\left.v_{\max }, \mathrm{cm}^{-1}\right): 3423(\mathrm{NH}), 3052\left(\mathrm{C}-\mathrm{H}_{\text {arom }}\right), 2921,2849$ $\left(\mathrm{C}-\mathrm{H}_{\text {alkyl }}\right), 1699(\mathrm{C}=\mathrm{O})$. MS (EI) $(70 \mathrm{eV}) \mathrm{m} / \mathrm{z}(\%): 313\left(\mathrm{M}^{++}\right.$, 36), 270 (11), 256 (7), 240 (22), 172 (9), 155 (100), 127 (89), 105 (56), 91 (27), 77 (33). Anal. calcd. (found) for $\mathrm{C}_{20} \mathrm{H}_{15} \mathrm{~N}_{3} \mathrm{O}$ : C, 76.66(76.49); H, 4.82(4.90); N, 13.41(13.23).

Crystal structure determination of compound 1,3,5-triphenyl4,5-dihydro-1H-pyrazol-4-ol (2c):

A suitable single crystal of $\mathbf{2} \mathbf{c}$ has been selected and mounted onto thin glass fiber. The X-ray single crystal diffraction data were collected at the ambient temperature (298 K) on an EnrafNonius 590 diffractometer with a Kappa CCD detector [17]. Reflection data has been recorded in the rotation mode using the $\phi$ and $\omega$ scan technique. The structure was solved using direct methods with SHELXS97 [18] and refined on F2 using all data by full-matrix least square procedures with SHELXS97 [18] implemented in maXus program suit [19]. The nonhydrogen atoms were refined with anisotropic displacement parameters. All hydrogen atoms were positioned geometrically and were initially refined with soft restraints on the bond lengths and angles to regularize their geometry $(\mathrm{C}-\mathrm{H}$ in the range 0.93 $0.98, \mathrm{O}-\mathrm{H}=0.82$ and $\mathrm{N}-\mathrm{H}$ in the range $0.86-0.89)$ and $\mathrm{U}_{\text {iso }}(\mathrm{H})$ (in the range 1.2-1.5 times $\mathrm{U}_{\text {eq }}$ of the parent atom). Then, the positions were refined with riding constraints [20]. The generalpurpose crystallographic tool PLATON [21] was used for the structure analysis and presentation of the results. The molecular graphics were done using ORTEP-3 for Windows [22] and DIAMOND [23] programs. Details of the data collection conditions and the parameters of the refinement are given in Table-1.

The full crystallographic information can be obtained free of charge using deposit number CCDC 1439398, via http:// www.ccdc.cam.ac.uk/conts/retrieving.html or from the Cambridge Crystallographic Data Centre, 12 Union Road, Cambridge CB2 1EZ, UK; fax: (+44) 1223-336-033; or email: deposit@ccdc.cam.ac.uk.

Assessment of the antimicrobial activity using the agar well diffusion technique: The chemically synthesized compounds were screened for their antibacterial and antifungal activities using the agar well diffusion technique [24]. The microorganisms (reference and clinical isolates) used include
E. coli (ATCC-25923), Salmonella typhi, Staphylococcus aureus (ATCC-25923), Candida albicans (ATCC-10231) and Aspergillus flavus. For the antibacterial assay, a standard inoculum $\left(10^{5} \mathrm{CFU} / \mathrm{mL}\right)$ was distributed on the surface of the agar plates using a sterile glass spreader, whereas for the antifungal assay a loopfull of a particular fungal isolate was transferred to $(3 \mathrm{~mL})$ sterile saline to get a suspension of the corresponding species; $(0.1 \mathrm{~mL})$ of the spore suspension was distributed on the surface of sterile Sabouraud dextrose agar plates. Six millimeter diameter wells were punched in the agar media and filled with $100 \mu \mathrm{L}$ of the tested chemical compound $(500 \mu \mathrm{g} / \mathrm{mL}$ in DMSO) which is previously sterilized through 0.45 sterile membrane filter. The plates were kept at room temperature for $1-2 \mathrm{~h}$, then incubated at $37^{\circ} \mathrm{C}$ for $24 \mathrm{~h}$ for bacteria and at $30{ }^{\circ} \mathrm{C}$ for 4 days for fungi. Commercial antibiotic discs were used as positive reference standard to determine the sensitivity of the strains [25].

Determination of the minimum inhibitory concentration (MIC) of the chemical compounds: Compounds inhibiting the growth of the above microorganisms were tested for their MIC by the broth dilution method [26]. The nutrient broth and the yeast extract broth media containing $1 \mathrm{~mL}$ of the serial dilutions of the tested compounds (3.125, 6.25, 12.5, 25,50 $\mu \mathrm{g} / \mathrm{mL}$ ) were inoculated with the microbial strains, the bacterial cultures were incubated at $37^{\circ} \mathrm{C}$ for $24 \mathrm{~h}$, whereas the fungal ones were incubated at $30^{\circ} \mathrm{C}$ for $48 \mathrm{~h}$. The lowest concentration required to arrest the microbial growth was regarded as the MIC of the tested compounds.

\section{RESULTS AND DISCUSSION}

Grinding of $\alpha, \beta$-epoxy ketones (1a,1b) $[15,16]$ with hydrazine hydrate and/or phenyl hydrazine at room temperature in a porcelain mortar under solvent-free conditions produced stable pyrazoline-4-ol derivatives (2a-d) in shorter reaction time (5-7 min) and high yields (80-93\%). However, refluxing solution of $\mathbf{1 a}, \mathbf{b}$ with hydrazine hydrate and/or phenyl hydrazine in ethanol afforded the same compounds $\mathbf{2 a - d}$ in a longer reaction time and moderate to high yields (59-83\%). The reaction probably takes place according to the following Scheme-I. Treating solutions of $\mathbf{1 a}$ and $\mathbf{1} \mathbf{b}$ with hydroxylamine hydrochloride in benzene and in the presence of a catalytic amount of triethyl amine gave the isoxazoline-4-ol derivatives (3a,b) as shown in Scheme-I. However, the reaction failed under solvent free grinding conditions. $\alpha, \beta$-Epoxy ketones are considered as a unique scaffold for synthesis of stable hydroxy azoles [27].

TABLE-1

SINGLE CRYSTAL EXPERIMENTAL DETAILS OF 2c (SEE THE SUPPLEMENTARY FILE WHICH CONTAINS 2c-REVISED.CIF AND ORT VIEW MATRIX)

\begin{tabular}{ll}
\hline Crystal data & $1,3,5$-Triphenyl-4,5-dihydro- $1 H$-pyrazol-4-ol (2c) \\
CCDC & 1439398 \\
Chemical formula & $\mathrm{C}_{21} \mathrm{H}_{18} \mathrm{~N}_{2} \mathrm{O}$ \\
$\mathrm{M}_{\mathrm{r}}$ & 314.39 \\
Crystal system, space group & Triclinic, P-1 \\
Temperature $(\mathrm{K})$ & 298 \\
$\mathrm{a}, \mathrm{b}, \mathrm{c}(\AA)$ & $11.9162(4), 12.4930(5), 13.9404(7)$ \\
$\mathrm{a}, \mathrm{b}, \mathrm{g}\left({ }^{\circ}\right)$ & $108.9591(14), 113.268(2), 95.0969(14)$ \\
$\mathrm{V}\left(\AA^{3}\right)$ & $1745.84(13)$ \\
$\mathrm{Z}$ & 4 \\
No. of measured, independent and observed $[\mathrm{I}>2 \sigma(\mathrm{I})]$ reflections & $8904,8904,1228$ \\
\hline
\end{tabular}




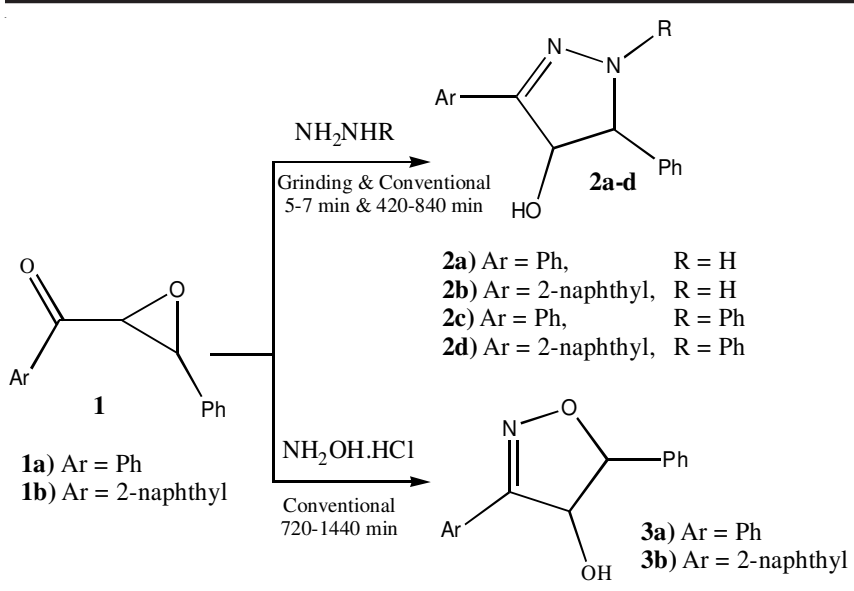

Scheme-I: Synthesis of pyrazoles $\mathbf{2 a - d}$ and 1, 2-oxazoles 3a,b

Structures of the synthesized pyrazolin-4-ol derivatives 2a-d and 1,2-oxazolin-4-ol derivatives (3a,b) was confirmed from: (i) The data obtained from previously similar work [28]. (ii) Their microanalytical and spectral data. Thus, their infrared (IR) spectra showed broad bands corresponding to bonded $\mathrm{OH}$ groups in the range $3490-3313 \mathrm{~cm}^{-1}$ and bands at $1613-$ $1584 \mathrm{~cm}^{-1}$ correlated to $\mathrm{C}=\mathrm{N}$ groups. Their ${ }^{1} \mathrm{H}$ NMR of $\mathbf{2 a - d}$, $\mathbf{3 a}, \mathbf{b}$ revealed signals due to two adjacent methine protons and aromatic protons and in addition to $\mathrm{OH}$ protons that exchangeable with $\mathrm{D}_{2} \mathrm{O}$ shake. The ${ }^{13} \mathrm{C}$ NMR spectra of compounds 2a, 2d and $\mathbf{3 b}$ showed signals corresponding to their carbon atoms skeleton

Mass spectra showed the molecular ion $\mathrm{M}, \mathrm{M}-\mathrm{H}_{2} \mathrm{O}, \mathrm{M}-$ $\mathrm{OH}$ peaks and mass fragmentation pattern in accord with the presence of $\mathrm{OH}$ group in their proposed structures.

Grinding 1a,b with urea and/or thiourea in a porcelain mortar and pestle in the presence of a few drops of acetic anhydride for 3-10 min afforded imidazolidine derivatives 4a-d after shorter reaction time (3-10 $\mathrm{min}$ ) with high yields (82$86 \%)$. Treatment of solutions of epoxides $\mathbf{1 a}$ and $\mathbf{1 b}$ in ethanol with urea and/or thiourea in the presence of catalytic amounts of potassium hydroxide afforded same compounds $\mathbf{4 a - d}$ after longer reaction time (2-3 h) with yields (71-80\%). Similar, treatment of 1a and $\mathbf{1 b}$ with guanidine hydrochloride gave oxazolidine derivatives $\mathbf{5 a}$ and $\mathbf{5 b}$, respectively, however, the reaction failed under grinding conditions. On the other hand, the reactions of compounds $\mathbf{1 a}, \mathbf{b}$ with semicarbazide afforded 1, 3, 4-oxadiazin derivative $\mathbf{6}$ and pyrazole derivative 7, respectively under grinding and conventional techniques as shown in Scheme-II.

Scheme-II shows that pyrazolidines $\mathbf{4}$ and oxazolidines 5 contains $\mathrm{C}=\mathrm{O}$ group which means that the reaction may go via a mechanism based on the behaviour of ureas and guanidine as bis-nucleophiles started attack by $\mathrm{NH}_{2}$ group of ureas and/ or guanidine on the $\beta$-carbon atom of keto-oxiranes to give an open chain non-isolable intermediate which under-goes cyclodehydration or cyclo-deammoniation on $\alpha$-carbon atom of oxirane ring to give compounds 4-, 5-, respectively.

The structures of the synthesized compounds 4-7 were supported from: (i) The data from previously similar work with thiourea and semicarbazides [28]. (ii) Their microanalytical and spectral data. Thus, their infrared spectra showed absorption bands correlated with their NH groups in the range 3423-3187

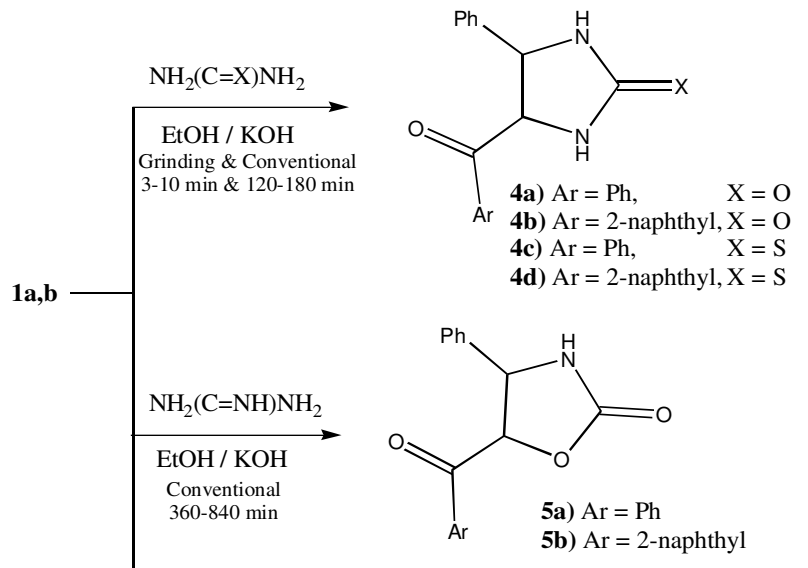

$\mathrm{NH}_{2} \mathrm{NH}(\mathrm{C}=\mathrm{O}) \mathrm{NH}_{2} \quad / \mathrm{KOH} / \mathrm{EtOH}$

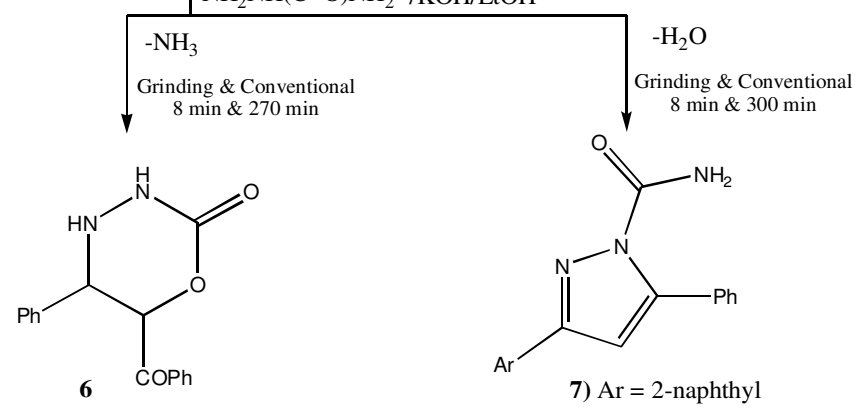

Scheme-II: Synthesis of imidazolidines $\mathbf{4 a - d , ~ 1 , 3 - o x a z o l i d i n e s ~ 5 a , b , ~}$ oxadiazine 6 and pyrazole 7 derivatives

$\mathrm{cm}^{-1}$ and bands at $1727-1631 \mathrm{~cm}^{-1}$ due to $\mathrm{C}=\mathrm{O}$ groups. Their ${ }^{1} \mathrm{H}$ NMR spectra showed absorption signals of the two adjacent methine protons with coupling constant in the range 13.2-14.1 $\mathrm{Hz}$, except compound 7 didn't show these signals; in addition to signals of their aromatic protons and broad signals in the down field region for $\mathrm{NH}$ protons that exchangeable with $\mathrm{D}_{2} \mathrm{O}$ shake. The ${ }^{13} \mathrm{C}$ NMR spectra showed carbon chemical shift values of compounds $\mathbf{4 b}, \mathbf{5 b}$ and $\mathbf{7}$ correspond very well with their carbon atoms. Their mass spectra showed the molecular ion peaks and mass peaks inconsistent with their proposed structures.

In order to compare the efficiency of green grinding [12] and conventional (thermal) reactions leading to the target heterocycles 2, 4, 6 and 7 and their associated economy. We used the concept of atom economy (AE) [29] to expresses the efficiency of the reactants to give the desired product. However, the atom economy values were the same for the mechanochemical and conventional procedures because we used two alternative reaction conditions to obtain the same target compounds.

We consequently introduced yield economy (YE) $[13,14]$ as a metric to assess the conversion efficiency of these two different approaches. The yield economy basically measures how much yield (\%) of the desired product is obtained over a certain reaction time (i.e., yield (\%)/reaction time (min)). A higher yield economy is, therefore, indicative of a higher level of conversion and much more efficient chemical process and more economical reaction. The yield economy of a reaction can be calculated using the following equation.

Yield economy $($ YE $)=$ Yield $(\%) /$ Reaction time $(\min )[13,14]$ 
Yield economy was used in this study to provide a decisive assessment of the yields obtained under the mechanochemical and conventional conditions (Table-1). Assessing a chemical reaction based entirely on its percentage yield can be misleading $[13,14]$. For example, the yields for compound $2 \mathbf{a}$ under the mechanochemical and conventional conditions were 93 and $83 \%$, respectively, with a difference of only $10 \%$. However, the yield economy values for the mechanochemical and conventional conditions were 18.6 and 0.19 , respectively, representing a much bigger difference and highlighting the of the former approach. Similar trends were observed for all of the other compounds in the series. The yield economy values of 2-7 are listed in Table-2.

It is observed from Table-2, that the mechano [Grindstone] green synthesis of the target heterocyclic compounds takes place under solvent free conditions in a shorter time with high yield economies and low energy in comparison with the conventional thermal reactions. That is due to the fact that, in solutions, particles get the energy to react from heat. But in grinding, energy is imparted through friction.

Crystal structure of 2c: Single crystal X-ray diffraction results of the compound 1, 3,5-triphenyl-4,5-dihydro- $1 H$-pyrazol4-ol (2c) found it to be crystallized in a triclinic system with space group P-1 possessing four molecules in the unit cell. The crystal structure contains two independent molecules in the asymmetric unit with almost identical conformation as shown in ORTEP view (Fig. 1). The structure of $\mathbf{2 c}$ represents a pyrazoline derivative, where pyrazol-4-ol moiety attached with three phenyl rings at the atoms C2, C4 and N6 (referring to one of the independent molecules for simplicity), as shown in Fig. 1.

The consistency of the geometrical parameters of the structure was performed through MOGUL software and Cambridge Structural Database (CSD V5.36) [30]. MOGUL search was selected to base the choice of similar fragments in

TABLE-2

PHYSICAL DATA OF THE TARGET HETEROCYCLES (2-7) UNDER GRINDING AND CONVENTIONAL (THERMAL) REACTIONS

\begin{tabular}{|c|c|c|c|c|c|c|c|c|}
\hline \multirow{2}{*}{ No. } & \multicolumn{3}{|c|}{ Thermal method } & \multicolumn{3}{|c|}{ Grinding method } & \multirow{2}{*}{$\mathrm{AE}$} & \multirow{2}{*}{$\mathrm{YE}(\mathrm{Th} / \mathrm{G})$} \\
\hline & Time (min) & Yield (\%) & m.p. $\left({ }^{\circ} \mathrm{C}\right)$ & Time (min) & Yield (\%) & m.p. $\left({ }^{\circ} \mathrm{C}\right)$ & & \\
\hline $2 a$ & 420 & 83 & $198-0$ & 5 & 93 & $200-2$ & 86.92 & $0.19 / 18.6$ \\
\hline $2 b$ & 360 & 65 & $200-2$ & 7 & 90 & $200-1$ & 88.89 & $0.18-12.85$ \\
\hline $2 c$ & 600 & 77 & $140-1$ & 7 & 85 & $140-1$ & 94.57 & $0.12 / 12.14$ \\
\hline $2 d$ & 840 & 59 & $186-9$ & 6 & 80 & $184-5$ & 95.29 & $0.07 / 13.33$ \\
\hline $3 a$ & 720 & 74 & $158-0$ & - & - & - & 81.14 & - \\
\hline $3 b$ & 1440 & 57 & $168-0$ & - & - & - & 84.15 & - \\
\hline $4 a$ & 120 & 80 & $182-4$ & 3 & 86 & $180-1$ & 93.66 & $0.66 / 28.66$ \\
\hline $4 b$ & 180 & 81 & $232-5$ & 5 & 86 & $229-0$ & 94.61 & $0.45 / 17.2$ \\
\hline $4 c$ & 150 & 71 & $214-6$ & 4 & 82 & $215-8$ & 94 & $0.47 / 20.5$ \\
\hline $4 d$ & 180 & 80 & $187-0$ & 10 & 88 & $186-8$ & 94.86 & $0.44 / 8.80$ \\
\hline $5 a$ & 840 & 84 & $288-0$ & - & - & - & 83.57 & - \\
\hline $5 b$ & 360 & 90 & $138-0$ & - & - & - & 85.80 & - \\
\hline 6 & 270 & 40 & $202-5$ & 8 & 60 & $202-4$ & 94.31 & $0.14 / 7.50$ \\
\hline 7 & 300 & 39 & $118-0$ & 8 & 86 & $119-0$ & 89.68 & $0.13 / 10.75$ \\
\hline
\end{tabular}

NOTE: $\mathrm{AE}=$ atom economy, $\mathrm{YE}=$ yield economy

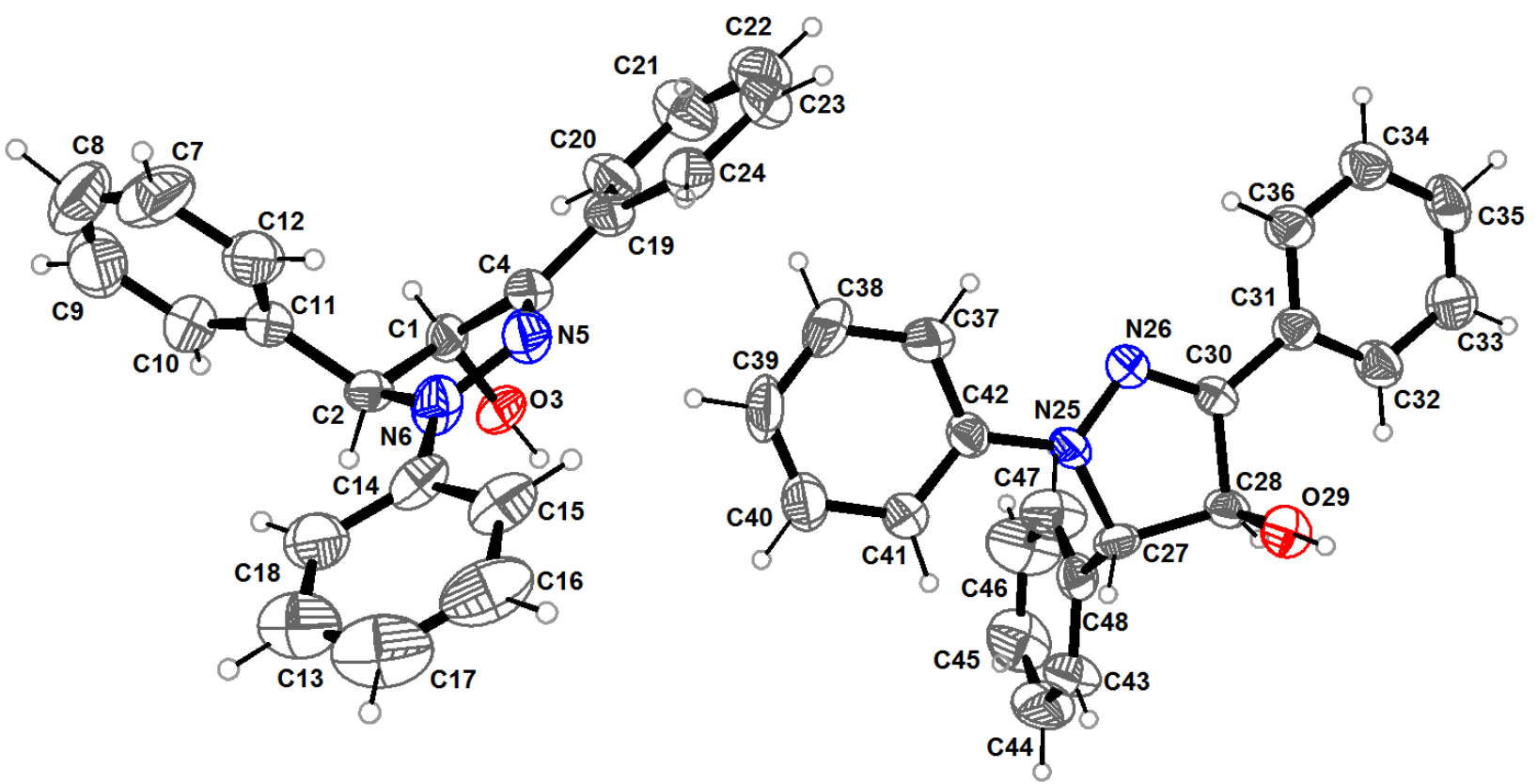

Fig. 1. A view of the structure of the two independent molecules of (2C), A left and $\mathbf{B}$ right; showing the atom-labeling scheme. Displacement ellipsoids are drawn at the $30 \%$ probability level 
the CSD considering that the unusual report of exact fragments must have numbers less than 15 to bonds, angles and rings and 40 to torsion angles. The results showed that the bond lengths, bond angles and torsions are in good agreement with each other and also with pre-determined structures having similar moieties.

However, MOGUL reported slight differences, in C2-N6 bond length $(1.443 \AA$ ) where the nearest bond length in the MOGUL distribution is $1.451 \AA$. Also, the torsion angles C10C11C2N6 and C12C11C2N6 where the difference between their values and the nearest torsion angles in the MOGUL distribution (dmin) are $0.143^{\circ}$ and 1.869 respectively. This slight variation could be explained due to the effect of the steric hindrance and crystal packing.

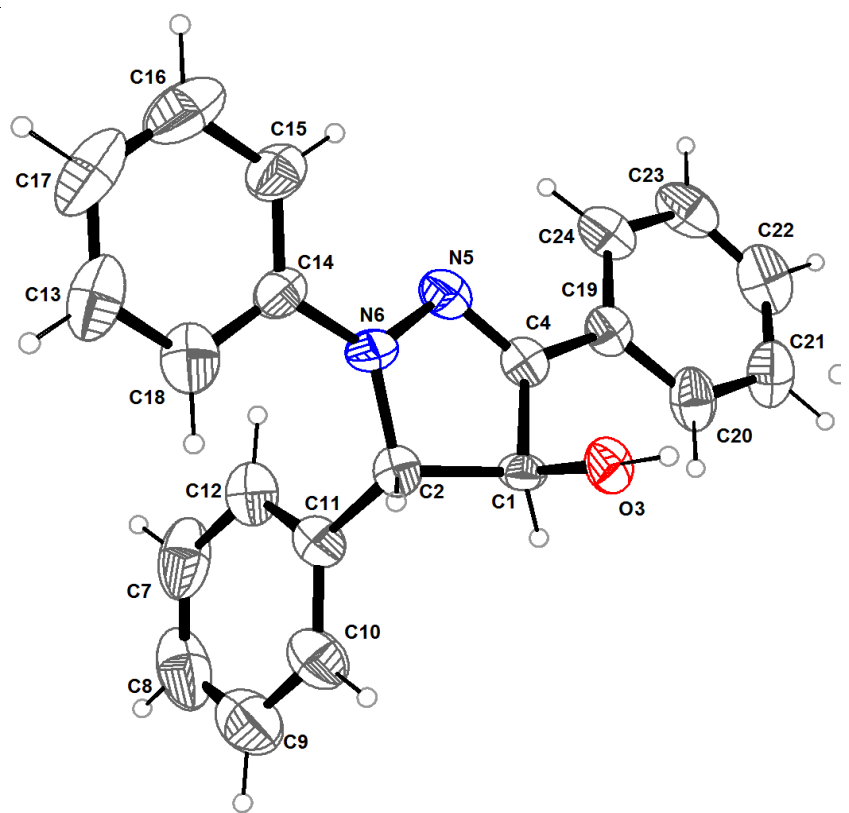

Fig. 2. Molecular structure of one of the independent molecules (A) of $2 \mathrm{C}$ shows the atom labeling. Displacement ellipsoids are drawn at the $30 \%$ probability level

Calculations of the least-squares plane passing through the consisting atoms of every moiety separately in the two independent molecules (Fig. 1) showed planar configurations in the phenyl rings $(\mathrm{C} 19 \rightarrow \mathrm{C} 24, \mathrm{C} 7 \rightarrow \mathrm{C} 12$ and $\mathrm{C} 14 \rightarrow \mathrm{C} 18)$ of $\mathrm{A}$ and $(\mathrm{C} 37 \rightarrow \mathrm{C} 42, \mathrm{C} 43 \rightarrow \mathrm{C} 48$ and $\mathrm{C} 31 \rightarrow \mathrm{C} 36)$ in $\mathrm{B}$, with maximum deviation of $0.012(8) \AA$ for $\mathrm{C} 12$ in $\mathrm{A}$ and 0.012 (2) $\AA$ for atom $\mathrm{C} 42$ of $\mathbf{B}$.

Stereochemical feature (2C) [envelop conformation]: The crystal structure identified the most important stereo chemical features of $\mathbf{2 C}$, where the pyrazole ring has an envelope conformation, the ring is twisted about the $\mathrm{C} 1-\mathrm{C} 2$ bond with the flap atom C2 which lies 0.138(7) $\AA$ out of the plane of the remaining four atoms. The same envelope feature was found in $\mathrm{B}$ for the pyrazole ring, which is twisted about the C28C27 bond with the flap atom C28 which lies 0.113(7) ̊ out of the plane of the remaining four atoms [31].

The structure of $\mathbf{2 C}$ is stabilized by the intermolecular interactions as well as a network of hydrogen bond contacts, confirmed parallel layers $\mathrm{O}-\mathrm{H}$-..O (Table-3). The packing diagram of the compound is shown in Fig. 3.

\begin{tabular}{|c|c|c|c|c|}
\hline \multicolumn{5}{|c|}{$\begin{array}{c}\text { TABLE-3 } \\
\text { HYDROGEN-BOND GEOMETRY }\left(\AA,{ }^{\circ}\right) \text { OF } \mathbf{2 C}\end{array}$} \\
\hline D-H $\cdots A$ & D-H & $\mathrm{H} \cdots \mathrm{A}$ & $\mathrm{D} \cdots \mathrm{A}$ & D-H $\cdots A$ \\
\hline $\mathrm{O} 3-\mathrm{H} 3 \cdots \mathrm{O} 29^{\mathrm{i}}$ & $0.960(6)$ & $2.191(7)$ & $2.722(6)$ & $114.2(6)$ \\
\hline $\mathrm{C} 29-\mathrm{H} 29 \cdots \mathrm{O} 3^{\mathrm{ii}}$ & $0.960(3)$ & $2.242(4)$ & $2.725(5)$ & $110.1(2)$ \\
\hline
\end{tabular}

Symmetry codes: (i) 1-x, 1-y,-z; (ii) $1+\mathrm{X}, \mathrm{Y}, \mathrm{Z}$

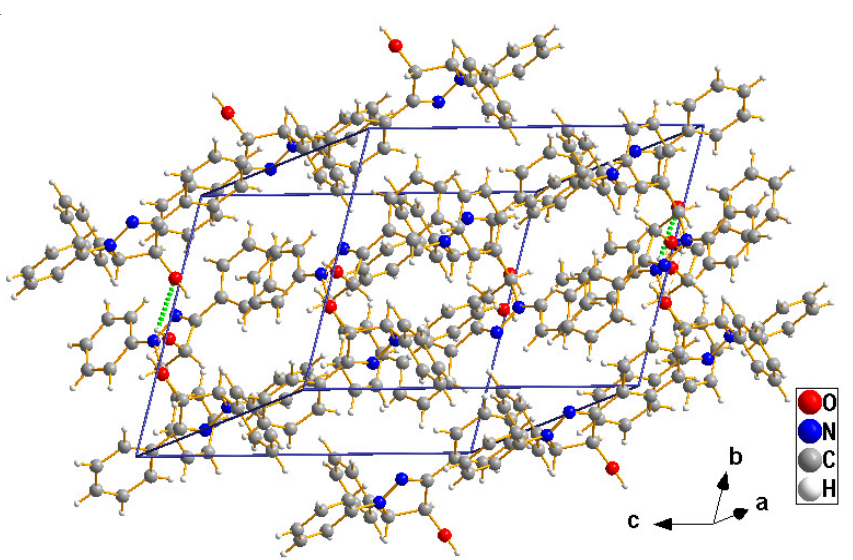

Fig. 3. A view of the molecular packing of the compound $2 \mathrm{C}, \mathrm{O}-\mathrm{H} \cdots \mathrm{O}$ interactions are shown as green dashed lines

The molecular packing explains the stability of hydroxy azoles towards aromatization due to the strong hydrogen bonding once it is formed.

Screening of the antimicrobial activity of the chemically synthesized compounds: The possible antimicrobial activities of the synthesized heterocyclic compounds $\mathbf{2 b}, \mathbf{2 d}$, $\mathbf{3 b}, \mathbf{4 b}, \mathbf{4 d}$ and $\mathbf{5 b}$ were investigated against five reference microbial isolates including; Gram-negative Escherichia coli (ATCC-25922) and Salmonella typhi, Gram-positive Staphylococcus aureus (ATCC-25923) and Fungi Candida albicans (ATCC-10231) and Aspergillus flavus as shown in Table-4.

\begin{tabular}{cccccc}
\multicolumn{7}{c}{ TABLE-4 } \\
\multicolumn{7}{c}{$\begin{array}{c}\text { ANTIMICROBIAL ACTIVITY OF CHEMICALLY } \\
\text { SYNTHESIZED COMPOUNDS }\end{array}$} \\
\hline Compd. & \multicolumn{5}{c}{ Inhibition zone diameter (mm/mg sample) } \\
\cline { 2 - 6 } No. & E. & S. & S. & C. & A. \\
& coli & typhi & aureus & albicans & flavus \\
\hline 2b & 33 & 29 & 33 & 20 & 23 \\
2d & 33 & 29 & 32 & 21 & 22 \\
3b & 34 & 32 & 34 & 21 & 21 \\
4b & 35 & 33 & 35 & 24 & 25 \\
4d & 34 & 31 & 33 & 20 & 23 \\
5b & 34 & 32 & 33 & 24 & 24 \\
S & 38 & 35 & 35 & $\mathrm{~N}$ & $\mathrm{~N}$ \\
F & $\mathrm{N}$ & $\mathrm{N}$ & $\mathrm{N}$ & 30 & 27 \\
\hline S & & &
\end{tabular}

$\mathrm{S}=$ Sulfamethoxazol $10 \mu \mathrm{g} / \mathrm{mL}$ (antibacterial agent); F = Fluconazol $10 \mu \mathrm{g} / \mathrm{mL}$ (antifungal agent). The concentration of all synthesized compounds were $(500 \mu \mathrm{g} / \mathrm{mL}$ in DMSO $) ; 0.0=$ no inhibition. $\mathrm{N}=$ not tested.

The tested compounds $\mathbf{2 b}, \mathbf{2} \mathbf{d}, \mathbf{3 b}, \mathbf{4 b}, \mathbf{4 d}$ and $\mathbf{5 b}$ are exhibited a high activity against both Escherichia coli (ATCC25922) and Salmonella typhi (as examples of Gram-negtive), Staphylococcus aureus (ATCC-25923) (as example of Grampositive), Candida albicans (ATCC-10231) (pathogenic yeast) and Aspergillus flavus (pathogenic mould). The tested compounds 
were showed a zone of inhibition diameters ranged from 33 to $35 \mathrm{~mm}$ against $E$. coli, 29 to $33 \mathrm{~mm}$; against $S$. typhi and 32 to $35 \mathrm{~mm}$ against $S$. aureus, at $500 \mathrm{mg} / \mathrm{mL}$ of DMSO. In comparison with fluconazol, the tested compounds were showed a zone of inhibition diameters ranged from 20 to $24 \mathrm{~mm}$ and 21 to $25 \mathrm{~mm}$ against $C$. albicans and A. flavus respectively at 500 $\mathrm{mg} / \mathrm{mL}$ of DMSO. Evident MIC values on the entire set of the tested microbial organism were determined for the chemical agents $\mathbf{2 b}, \mathbf{2 d}, \mathbf{3 b}, \mathbf{4 b}, \mathbf{4 d}$ and $\mathbf{5 b}$ and the results are summarized in Table-5. The MIC values are ranged from $6.25 \mu \mathrm{g}$ to 12.5 $\mu \mathrm{g}$ in case of all chemically synthesized compounds against all used microbial. Compounds $\mathbf{4} \mathbf{b}$ and $\mathbf{5 b}$ are the most potent compounds.

\begin{tabular}{|c|c|c|c|c|c|}
\hline \multicolumn{6}{|c|}{$\begin{array}{c}\text { TABLE-5 } \\
\text { MINIMUM INHIBITION CONCENTRATION (MIC) OF } \\
\text { THE CHEMICALLY SYNTHESIZED COMPOUNDS }\end{array}$} \\
\hline \multirow{2}{*}{$\begin{array}{c}\text { Compd. } \\
\text { No. }\end{array}$} & \multicolumn{5}{|c|}{ MIC values $(\mu \mathrm{g} / \mathrm{mL})$} \\
\hline & $\begin{array}{c}E \text { coli } \\
\text { coli }\end{array}$ & $\begin{array}{c}S . \\
\text { typhi }\end{array}$ & $\begin{array}{c}S . \\
\text { aureus }\end{array}$ & $\begin{array}{c}C . \\
\text { albicans }\end{array}$ & $\begin{array}{c}\text { A. } \\
\text { flavus }\end{array}$ \\
\hline $2 \mathbf{b}$ & 12.5 & 12.5 & 12.5 & 12.5 & 12.5 \\
\hline $2 d$ & 12.5 & 12.5 & 6.25 & 12.5 & 6.25 \\
\hline $3 \mathbf{b}$ & 12.5 & 12.5 & 6.25 & 6.25 & 12.5 \\
\hline $4 b$ & 6.25 & 12.5 & 6.25 & 6.25 & 6.25 \\
\hline 4d & 12.5 & 12.5 & 12.5 & 6.25 & 12.5 \\
\hline $\mathbf{5 b}$ & 6.25 & 6.25 & 6.25 & 6.25 & 6.25 \\
\hline $\mathrm{S}$ & 3.125 & 3.125 & 3.125 & $\mathrm{~N}$ & $\mathrm{~N}$ \\
\hline $\mathrm{F}$ & $\mathrm{N}$ & $\mathrm{N}$ & $\mathrm{N}$ & 3.125 & 3.125 \\
\hline \multicolumn{6}{|c|}{$\begin{array}{l}\mathrm{S}=\text { Sulfamethoxazol } 10 \mu \mathrm{g} / \mathrm{mL} \text { (antibacterial agent); } \mathrm{F}=\text { Fluconazol } \\
10 \mu \mathrm{g} / \mathrm{mL} \text { (antifungal agent). The concentration of all synthesized } \\
\text { compounds were }(500 \mu \mathrm{g} / \mathrm{mL} \text { in DMSO); } 0.0=\text { no inhibition. } \mathrm{N}=\text { not } \\
\text { tested. }\end{array}$} \\
\hline
\end{tabular}

\section{Conculsion}

In summary promising biologically active heterocyclic compounds were obtained from the reaction of the $\alpha, \beta$-epoxy ketones as precursors originate $[\mathrm{OH}]$ groups in different efficient synthetic strategies for building stable hydroxyl azoles under grinding and conventional thermal conditions. The key advantages of grinding strategy over conventional approaches include its green [5], safe, simple, solvent-free conditions, as well as its facile work-up, high yield economy and environmental friendliness. Single crystal X-ray study identified the stereo-chemical structure of $\mathbf{2 C}$, which can be also considered as a guide for the prepared derivatives.

\section{REFERENCES}

1. S.R. Prasad, T. Sarawathy, V. Niraimathi and B. Indhumathi, Int. J. Pharm. Pharm. Sci., 4, 285 (2012).

2. D.J. Vishal, D.K. Mahendra and S. Sarita, J. Chem. Pharm. Res., 4, 3234 (2012).

3. E.M. Sharshira and N.M.M. Hamada, Molecules, 17, 4962 (2012); https://doi.org/10.3390/molecules17054962.

4. A. Verma, S. Joshi and D. Singh, J. Chem., 2013, 1 (2013); https://doi.org/10.1155/2013/329412.

5. J. Do and T. Friseic, ACS. Cent. Sci., 3, 13 (2017); https://doi.org/10.1021/acscentsci.6b00277.
6. R.M. Claramunt, C. López, D. Sanz and J. Elguero, Adv. Heterocycl. Chem., 112, 117 (2014); https://doi.org/10.1016/B978-0-12-800171-4.00003-2.

7. S. Zangade, S.S. Mokle, A.T. Shinde and Y. Vibhute, Green Chem. Lett. Rev., 6, 123 (2013); https://doi.org/10.1080/17518253.2012.713123.

8. S. Kumar, Green Chem. Lett. Rev., 7, 95 (2014); https://doi.org/10.1080/17518253.2014.895867.

9. M. Nikpassand, L.Z. Fekri, N. Changiz and F. Imani, Lett. Org. Chem., 11, 29 (2014); https://doi.org/10.2174/157017861101140113160517.

10. A.M. Abdel Hameed, Environ. Chem. Lett., 13, 125 (2015); https://doi.org/10.1007/s10311-015-0494-6.

11. A. Abdel-Aziem, Int. J. Pharm. Pharm. Sci., 7, 61 (2015).

12. S.L. James, C.J.Adams, C. Bolm, D. Braga, P. Collier, T. Friscic, F. Grepioni, K.D.M. Harris, G. Hyett, W. Jones, A. Krebs, J. Mack, L. Maini, A.G. Orpen, I.P. Parkin, W.C. Shearouse, J.W. Steed and D.C. Waddell, Chem. Soc. Rev., 41, 413 (2012); https://doi.org/10.1039/C1CS15171A.

13. A.F.M. Fahmy, A.A. El-Sayed and M.M. Hemdan, Chem. Cent. J., 10, 59 (2016); https://doi.org/10.1186/s13065-016-0205-9.

14. A.F.M. Fahmy, M.M. Hemdan, A.A. El-Sayed, A.I. Hassaballah and N. Ahmed, Int. J. Curr. Res., 8, 30483 (2016).

15. A. Lattanzi and A. Russo, Tetrahedron, 62, 12264 (2006); https://doi.org/10.1016/j.tet.2006.10.005.

16. T. Nemoto, T. Ohshima and M. Shibasaki, J. Synth. Org. Chem. Jpn., 60, 94 (2002); https://doi.org/10.5059/yukigoseikyokaishi.60.94.

17. X-ray Crystallography Laboratory, National Research Centre of Egypt (NRC), 1 January 2014.

18. G.M. Sheldrick, SHELXS-97, Program for Crystal Structure Solution and Refinement, University of Gottingen, Germany, p. 1456 (1997).

19. S. Mackay, C.J. Gilmore, C. Edwards, N. Stewart and K. Shankland, maXus Computer Program for the Solution and Refinement of Crystal Structures, Bruker Nonius. The Netherlands, Mac-Science, Japan \& The University of Glasgow (1999).

20. R.I. Cooper, A.L. Thompson and D.J. Watkin, J. Appl. Cryst., 43, 1100 (2010); https://doi.org/10.1107/S0021889810025598.

21. A.L. Spek, Acta Crystallogr. D Biol. Crystallogr., 65, 148 (2009); https://doi.org/10.1107/S090744490804362X.

22. L.J. Farrugia, J. Appl. Cryst., 45, 849 (2012); https://doi.org/10.1107/S0021889812029111.

23. K. Brandenburg, DIAMOND, Crystal Impact GbR, Bonn, Germany, (2012).

24. S. Naz, S. Jabeen, S. Ilyas, F. Manzoor, F. Aslam and A. Ali, Pak. J. Bot., 42, 455 (2010).

25. N.G. Kandile, H.T. Zaky, M.I. Mohamed, H.M. Ismaeel and N.A. Ahmed, J. Enzyme Inhib. Med. Chem., 27, 599 (2012); https://doi.org/10.3109/14756366.2011.576251.

26. C. Valgas, S.M. Souza, E.F.A. Smania and A. Smania Jr., Braz. J. Microbiol., 38, 369 (2007); https://doi.org/10.1590/S1517-83822007000200034.

27. S. El- Meligie, A.T. Taher, A.M. Kamal and A. Youssef, Eur. J. Med. Chem., 126, 52 (2017); https://doi.org/10.1016/j.ejmech.2016.09.099.

28. A. I. EL-Shenawy, Chem. Pap., 59, 196 (2005).

29. R.A. Sheldon, Pure Appl. Chem., 72, 1233 (2000); https://doi.org/10.1351/pac200072071233.

30. I.J. Bruno, J.C. Cole, M. Kessler, J. Luo, W.D.S. Motherwell, L.H. Purkis, B.R. Smith, R. Taylor, R.I. Cooper, S.E. Harris and A.G. Orpen, J. Chem. Inf. Comput. Sci., 44, 2133 (2004); https://doi.org/10.1021/ci049780b.

31. D. Cremer and J.A. Pople, J. Am. Chem. Soc., 97, 1354 (1975); https://doi.org/10.1021/ja00839a011. 